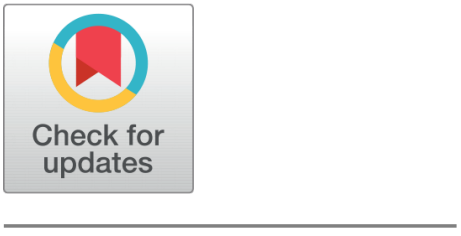

OPEN ACCESS

Received: 21.01.2021

Accepted: 27.03 .2021

Published: 17.04.2021

Citation: Balasuadhakar A (2021) Natural Convection Solar Dryers for Agricultural Products - A Comprehensive Exploration. Indian Journal of Science and Technology 14(13): 1021-1027. https://doi.org/ 10.17485/IJST/v14i13.126

* Corresponding author.

Tel: 00251928143114

balasudhakar24@gmail.com

Funding: None

Competing Interests: None

Copyright: (c) 2021 Balasuadhakar. This is an open access article distributed under the terms of the Creative Commons Attribution License, which permits unrestricted use, distribution, and reproduction in any medium, provided the original author and source are credited.

Published By Indian Society for Education and Environment (iSee)

ISSN

Print: 0974-6846

Electronic: 0974-5645

\section{Natural Convection Solar Dryers for Agricultural Products - A Comprehensive Exploration}

\author{
Arumugam Balasuadhakar ${ }^{1 *}$ \\ 1 School of Mechanical and Industrial Engineering, Dire Dawa University, Ethiopia. \\ Tel.: 00251928143114
}

\section{Abstract}

Objectives: To make review on passive solar dryers and its performance of drying agricultural products. Methods: This article focuses on the development in various categories of passive solar dryers in last six years. The different studies carried out in direct, indirect and mixed mode types of passive dryers for drying agricultural products in the year of 2014 to 2020 have been considered this review. Investigations on forced convection solar dryers have not been included in the current paper. The various experimental setups of solar dryers, specimens used for experimentation, measured output parameters and performance have been illustrated. The changes made in construction of solar dryers for improving the performance have also been reviewed. Findings:The mixed mode passive solar dryer is found to be superior in terms of drying time, better utilization of solar energy and efficiency compared to other passive dryers. Novelty: Several review articles have been published in solar dryers. Nevertheless, no comprehensive reviews have hitherto been published on passive dryers in particular. Hence, our current review article focuses on development in passive dryers and its advancements with emphasis on dryer design features, specimen and measured output parameters.

Keywords: Passive solar dryers; Natural convection solar dryers; Direct solar dryers; Indirect solar dryers; Mixed mode solar dryers

\section{Introduction}

Different kinds of solar dryers are available at variety of designs and various sizes based on the necessities ${ }^{(1)}$. Solar dryers are generally classified on the basis of contributions of solar energy, air direction, air movement mode, product used for drying and insulation materials ${ }^{(2)}$. Passive mode and active mode are the two main categories in solar dryers and the sub categories are indirect type dryers, direct type dryers and mixed mode type dryers.

The direct mode solar dryer is also known as cabinet dryer. The air entry is through the bottom side of cabinet and top vent is used for escaping the air. The moisture content from the drying product is observed by the air while passing through the cabinet. Solar energy is observed by an attached solar collector in indirect dryers. Drying chamber 
gets the heated air from collector for drying operation ${ }^{(3)}$. Direct and indirect solar dryers are constructed together and forms a mixed mode type solar dryer. In mixed mode type, the product is dried by both direct mode through the transparent cover and indirect mode ${ }^{(4)}$.

\section{Previous Research on Different Types of Passive Solar Dryers}

Table 1. Studies in different types of passive solar dryers

\begin{tabular}{|c|c|c|c|c|}
\hline Author & Dryer Type & Design Feature & Specimen & Measured output parameters \\
\hline Borah et al (2015) ${ }^{(5)}$ & & Conductive and convective dryer & Turmeric & Drying chamber temperature \\
\hline Chauhan et al (2016) ${ }^{(6)}$ & Direct & $\begin{array}{l}\text { Green house dryer insulated in } \\
\text { north side wall }\end{array}$ & $\begin{array}{l}\text { Vegetables } \\
\text { and fruits }\end{array}$ & $\begin{array}{l}\text { Chamber temperature, relative } \\
\text { humidity }\end{array}$ \\
\hline Tiwari et al (2016) ${ }^{(7)}$ & & $\begin{array}{l}\text { Green house dryer with PVT single } \\
\text { Roof }\end{array}$ & Crop & Crop temperature \\
\hline $\begin{array}{l}\text { Chatchawal et al } \\
(2017)^{(8)}\end{array}$ & & $\begin{array}{l}\text { Green house dryer with Parabolic } \\
\text { roof structure }\end{array}$ & Red chili & Moisture content \\
\hline Manpreet et al (2018) ${ }^{(9)}$ & & Solar cooker cum dryer & Gooseberry & $\begin{array}{l}\text { Absorber plate temperature, chamber } \\
\text { temperature, absorber glass tempera- } \\
\text { ture }\end{array}$ \\
\hline Chen et al (2014) ${ }^{(10)}$ & & Chimney type, porous absorber & $\begin{array}{l}\text { Porous } \\
\text { materials }\end{array}$ & Air flow temperature at chimney exit \\
\hline $\operatorname{Finck}(2014)^{(11)}$ & & $\begin{array}{l}\text { Variable steering flow arrangement } \\
\text { in absorber }\end{array}$ & Nopal & Moisture content, drying time \\
\hline Romero et al (2014) ${ }^{(12)}$ & Indirect & PVC chimney & Vanilla & Moisture content \\
\hline Musembi et al (2016) ${ }^{(13)}$ & Dryers & Collector with adjustable angle & Apple & Moisture content \\
\hline Slimani et al (2016) ${ }^{(14)}$ & & Photovoltaic/Thermal collector & $\begin{array}{l}\text { Agriculture } \\
\text { products }\end{array}$ & Inlet air temperature \\
\hline Hajar et al (2017) ${ }^{(15)}$ & & $\begin{array}{l}\text { Corrugated aluminum plate } \\
\text { absorber }\end{array}$ & Pear & $\begin{array}{l}\text { Drying chamber temperature, drying } \\
\text { time, moisture content, }\end{array}$ \\
\hline Essalhi et al (2018) ${ }^{(16)}$ & & $\begin{array}{l}\text { Dryer connected with water storage } \\
\text { tank }\end{array}$ & Grapes & Moisture content \\
\hline Swami et al (2018) ${ }^{(17)}$ & & $\begin{array}{l}\text { Absorber constructed with phase } \\
\text { change material }\end{array}$ & Fishes & Temperature of dryer, drying time \\
\hline Zoukit et al (2019) ${ }^{(18)}$ & & Aluminium finned absorber & $\begin{array}{l}\text { Agricultural } \\
\text { products }\end{array}$ & Drying chamber temperature \\
\hline Emetere et al (2019) ${ }^{(19)}$ & & $\begin{array}{l}\text { Hanger chamber and pipe for heated } \\
\text { air }\end{array}$ & Fruits & Moisture content \\
\hline Ugwu et al (2015) & & Pebble bed absorber & Timber & $\begin{array}{l}\text { Drying chamber temperature, mois- } \\
\text { ture content }\end{array}$ \\
\hline $\begin{array}{l}\text { Dejchanchaiwong et al } \\
(2016)^{(21)}\end{array}$ & Mixed & Concrete drying chamber & $\begin{array}{l}\text { natural rub- } \\
\text { ber sheets }\end{array}$ & Moisture content \\
\hline Sekyere et al (2016) ${ }^{(22)}$ & Mode & Dryer with backup heater & Crop & Moisture content \\
\hline Yassen et al (2016) ${ }^{(23)}$ & Dryers & $\begin{array}{l}\text { Dryer connected with biomass plant } \\
\text { recovery dryer }\end{array}$ & Red chili & Moisture content, drying time \\
\hline Mehta et al (2018) ${ }^{(24)}$ & & Tent type dryer & Fishes & Collector outlet air temperature \\
\hline $\begin{array}{l}\text { Ssemwanga et al } \\
(2020)^{(25)}\end{array}$ e & & $\begin{array}{l}\text { Multiple metallic concentrator col- } \\
\text { lector }\end{array}$ & $\begin{array}{l}\text { Pineapples, } \\
\text { mangoes }\end{array}$ & Moisture content, drying time \\
\hline $\begin{array}{l}\text { Mohammed et al } \\
(2020)^{(26)}\end{array}$ & & Multiple metallic concentrator & Pineapples & Moisture content \\
\hline Erick C et al (2020) & & Two way mode dryer & Tomatoes & $\begin{array}{l}\text { Drying chamber temperature, drying } \\
\text { time }\end{array}$ \\
\hline Sekyere et al (2020) ${ }^{(28)}$ & & $\begin{array}{l}\text { Dryer with three mode options, rock } \\
\text { piles collector }\end{array}$ & Grapes & Collector temperature \\
\hline
\end{tabular}




\subsection{Direct Dryers}

In ${ }^{(5)}$ carried out the experiment on turmeric drying in a direct mode solar dryer. The air temperature for drying was found between $39-51^{\circ} \mathrm{C}$ from the atmospheric air temperature range of $25-28^{\circ} \mathrm{C}$. In the $12 \mathrm{~h}$ of effective drying time the damp content was reduced to $6.36 \%$ in solid turmeric and $5.50 \%$ in turmeric slice from the initial value of $78.65 \%$. The overall thermal efficiency was evaluated by $55 \%$. It was found that the sliced turmeric had better kinetics and efficient in drying instead of solid form. In ${ }^{(6)}$ the authors analyzed the greenhouse dryer with insulation in north sidewall. Two different cases of experimentation had been carried out. The first one was direct dryer with solar collector and the other was greenhouse dryer with insulated wall. It was concluded that the insulated type green house dryer was most efficient as compared to conventional type greenhouse dryers.

$\mathrm{In}^{(7)}$ experimented a thermal modeling of greenhouse dryer with photovoltaic-thermal roof. The experimentation was carried out in natural and forced mode. It was found that the thermal energy reduced by $76.39 \%$ and electrical energy boosted by $88.73 \%$ with the increment in PV module packing factor value. The addition of mass flow rate influenced the thermal energy by $89.44 \%$ of natural convection and $65.70 \%$ of forced convection mode. $\operatorname{In}^{(8)}$ experimented a green house dryer and drying system with low temperature for red chili. In the night time drying, the wetness of chili decreased on average $0.02 \mathrm{~g} / \mathrm{h}$ and $0.193 \mathrm{~g} / \mathrm{h}$ on day time. The drying processes reduced the value of $13.55 \%$ of moisture content within $52 \mathrm{~h}$ duration.

In $^{(9)}$ designed a side loading solar cooker-cum-dryer with the multi-shelf arrangement for keeping drying product. A Booster mirror was used in north face for better performance during winter season as shown in Figure 1. It was identified that the solar radiation capture by designed modal was 16 to $54 \%$ upper in winter as compared with conventional horizontally placed solar cooker.

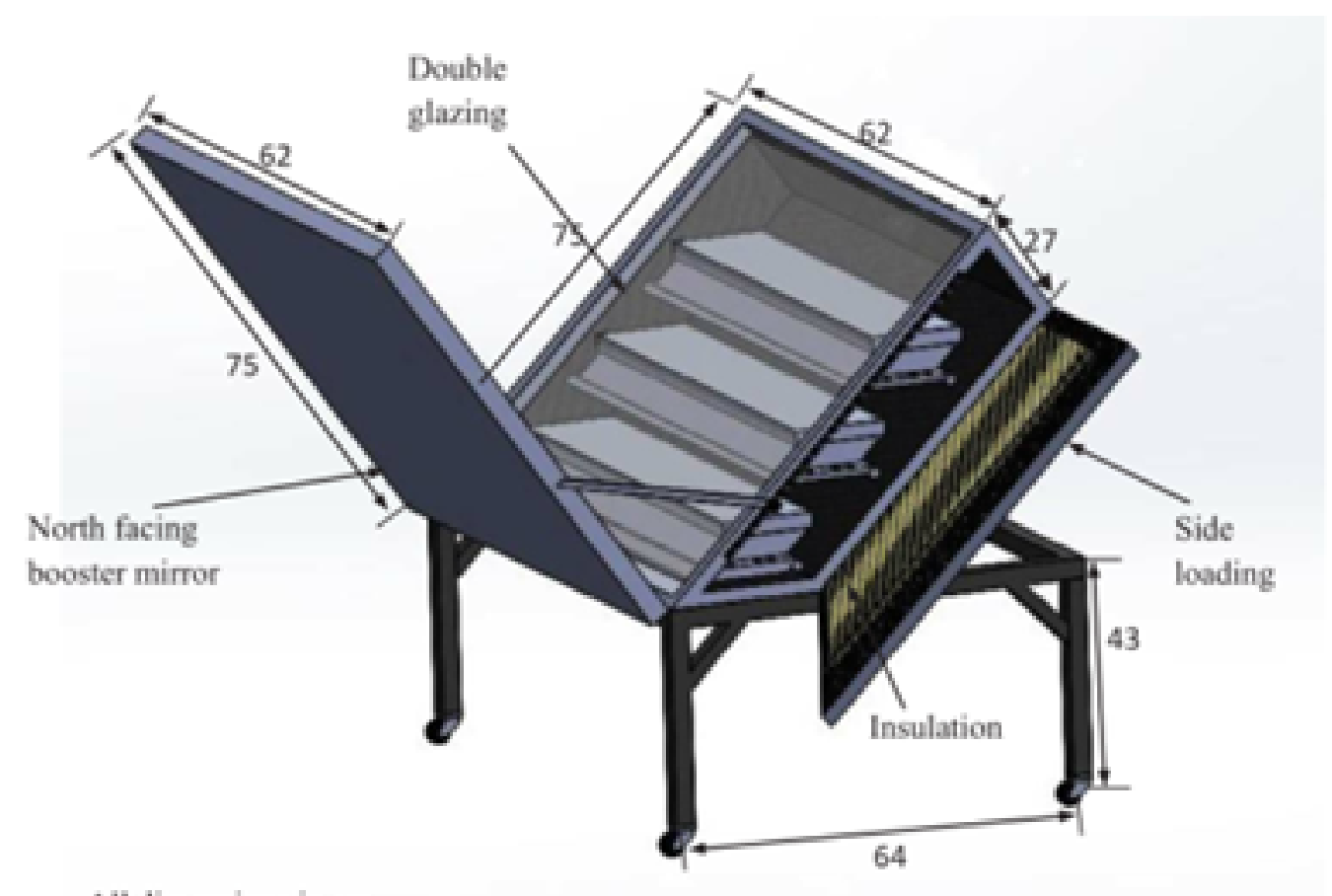

All dimensions in $\mathrm{cm}$

Fig 1. Solar cooker cum direct solar dryer ${ }^{(9)}$

\subsection{Indirect Dryers}

$\mathrm{In}^{(10)}$ authors analyzed the indirect type solar dryer. The dryer was constructed with porous solar collector and chimney. Heat transfer flow was analyzed in the solar absorbent by Brinkmane Darcy model and equations of energy. Effect of changes in height and leaning of dryer was also determined, ${ }^{(11)}$ constructed an indirect solar dryer with the dimensions of 1 " thick, $140 \mathrm{~cm}$ length and $60 \mathrm{~cm}$ width from the plywood wood and inclination was used to $17.5^{\circ}$ to the horizontal. Black painted coil of copper foil matt was adopted for absorber. The drying time of nopal was estimated by using the average speed of the entire process. 
In ${ }^{(12)}$ constructed a vanilla dryer prototype of $50 \mathrm{~kg}$ capacity. Theoretical and experimental analyze for distribution of temperature was achieved on the dryer. ${ }^{(13)}$ developed an indirect natural convection mode dryer for mid-latitude region. The specimens of apple slices were used to validate the model. Moisture value of fresh apple reduced to $8.12 \%$ from $86 \%$ in the duration of 9 hours 20 minutes. The calculated overall efficiency of the dryer was $17.89 \%$ at an average solar energy value of $534.45 \mathrm{~W} / \mathrm{m}^{2} . \mathrm{In}^{(14)}$ constructed a indirect dryer with photovoltaic and thermal solar collector. The thermal energy performance of a hybrid collector was evaluated. The thermal performance was increased by glazing of collector and the electrical performance was decreased. The PV/T collector efficiencies were calculated as $41.09 \%$ in thermal and $9.33 \%$ in electrical.

In ${ }^{(15)}$ tested a solar absorber which consisted of two aluminium corrugated sheets. Corrugated Sheets were joined in cylindrical shape for better air circulation in collector. The specimen mass value was reduced to $135.13 \mathrm{~g}$ from the initial mass of $997.3 \mathrm{~g}$ and average thermal efficiency was evaluated by $11.11 \%{ }^{(16)}$ analyzed the behavior of grapes drying process by indirect dryer and traditional open sun drying. Experimental results showed that the time required for grapes drying was $120 \mathrm{~h}$ in indirect dryer and $201 \mathrm{~h}$ in traditional drying. The moisture value was reduced to $20.2 \%$ from initial value of $79.8 \%{ }^{(17)}$ experimented the dryer and the drying chamber was constructed with phase change material as shown in Figure 2. The heating chamber depth was $10 \mathrm{~cm}$. The specimen used for experimentation was fish and placed in drying chamber. The Air flow rate was optimized as $5 \mathrm{~m} / \mathrm{s}$ at the mass flow value of $0.314 \mathrm{~kg} / \mathrm{s}$.

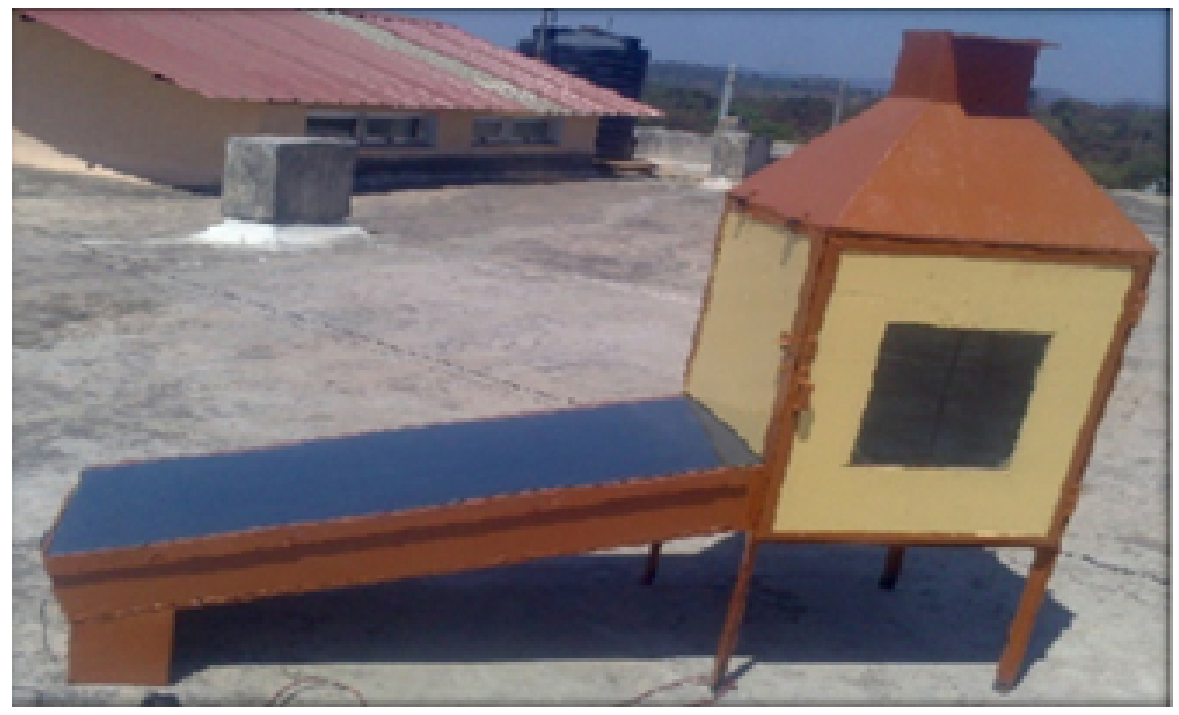

Fig 2. Indirect solar dryer with phase change material ${ }^{(17)}$

In ${ }^{(18)}$ applied fuzzy model for forecasting inside temperature value of chamber. The dryer was designed to operate in both active and passive mode. Experiment was carried out to find the reliability of the dryer. The Root Mean Square Error value was calculated in both mode of operation for comparison of forecasted to experimented temperature. It was resulted that the RMSE value was $0.81 \%$ in passive mode and $1.94 \%$ in active mode. ${ }^{(19)}$ developed indirect dryer made with concentrator chamber, transport pipe and hanger chamber. It was observed that the hanger chamber temperature was increased $15.2 \%$ in day $1,16.04$ $\%$ in day $2,20.14 \%$ in day 3 , and $13.57 \%$ in day 4.

\subsection{Mixed Mode Dryers}

In ${ }^{(20)}$ constructed a solar dryer of mixed mode category. The solar collector was constructed with black pebbles for storing and absorbing of solar energy as shown in Figure 3. Heat energy was observed by transparent roof of drying chamber and collector for making efficient process of drying. The capacity of a drying chamber and pebble bed were $0.362 \mathrm{~m}^{3}$ and $0.1 \mathrm{~m}^{3}$ respectively. The area of transparent roof and glazed flat plate collector was calculated as $0.54 \mathrm{~m}^{2}$. It was observed that the kiln temperatures were maintained above the ambient values during night. The moisture content value was reduced in okpeye timber to $12.9 \%$ from the initial value of $66.27 \%$ within 15 days. ${ }^{(21)}$ developed the mathematical model for mixed mode and indirect mode dryer. The natural rubber sheets were used for experimentation. It was found that the mixed mode dryer efficiency was $2.1 \%$ more than indirect dryer. The rubber sheets moisture contents were reduced $2.0 \%$ from $32.3 \%$ in mixed mode and $8 \%$ from 
$29.4 \%$ in indirect mode within 4 days.

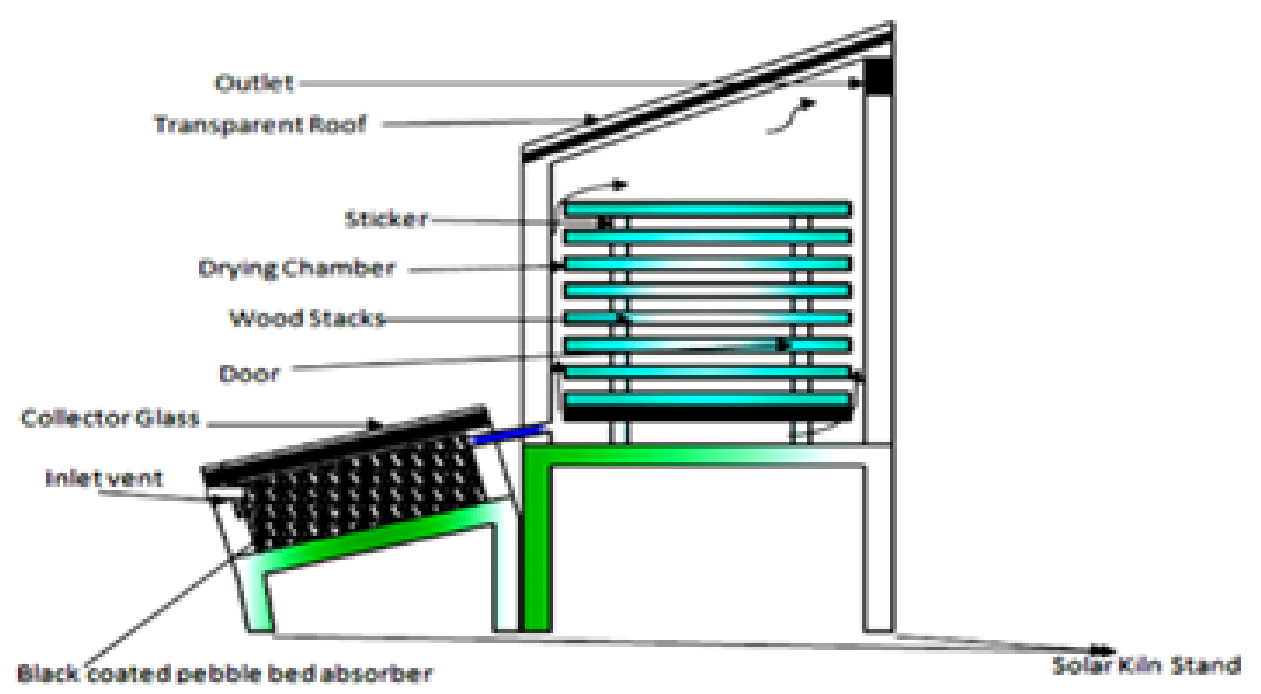

Fig 3. Mixed mode solar dryer ${ }^{(20)}$

In ${ }^{(22)}$ designed a natural convection solar dryer by local materials. The dryer was constructed with a backup electric heater and used in low radiation periods. The pineapple slices were used as a specimen and the experiment was conducted on four typical seasons in Ghana. The moisture value of specimens was reduced to $106 \%$ from $924 \%$ within 19 h at season $1,184 \%$ from $1049 \%$ within $10 \mathrm{~h}$ at season $2,155 \%$ from $912 \%$ within $7 \mathrm{~h}$ at season 3 and $144 \%$ from $1049 \%$ within $23 \mathrm{~h}$ at season 4 . The resulting efficiency of the dryer was obtained $27 \%$ at season $1,24 \%$ at season $2,11 \%$ at season 3 and $32 \%$ at season 4 . ${ }^{(23)}$ Designed a prototype of hybrid solar dryer with additional thermal energy system. The dryer integrated with secondary drying system. The secondary dryer was operated by exhaust flue gas from primary dryer. The red chilies were used for evaluating the performance of dryer. The results demonstrated that overall efficiency of hybrid dryer as $25.84 \%$ in day and night and thermal mode dryer as $29.7 \%$ in night time.

In ${ }^{(24)}$ designed a tent type mixed mode dryer. The mathematical model was developed to forecast collector outlet temperature. It was identified that the drying chamber temperature as $60-65^{\circ} \mathrm{C}$ and outlet dryer temperature as $50^{\circ} \mathrm{C}$. It was concluded that the dryer efficiency was $25.42 \%$ for $1 \mathrm{~kg}$ of fish. ${ }^{(25)}$ developed a hybrid type passive dryer. In this work the multiple metallic collectors were integrated with the dryer. The drying cabin was constructed with green house plastic material. It was fabricated a conventional type Photovoltaic active dryer for comparative study. The fruits were used for evaluating the performance of two category dryers and the results were compared with traditional sun drying method. The investigation concluded that the integration of multiple metallic solar collectors and specialized plastic greenhouse material with HIP solar dryer significantly improved the drying performance.

In ${ }^{(26)}$ designed an active mode Photovoltaic and Electric dryer and improved passive mode dryer for drying fruits. The comparative study in economic performance was analyzed and result showed that the improved passive dryer was better than the active dryer. ${ }^{(27)}$ developed a passive mode dryer with mobile opaque cover drying chamber. The dryer had the option of operating as an indirect mode and mixed mode. The experiment revealed that the tomato drying in indirect mode was 26 hrs and the mixed mode was 17 hrs. ${ }^{(28)}$ developed a mixed mode dryer. The backup solar heater was integrated with the dryer. The hybrid heating, back up heating and solar heating methods were employed to investigate the thermal performance of the dryer. The theoretical thermal performance of the dryer was predicted by mathematical model. The predicted values were accurate within the range of $0.20 \%$ to $7.49 \%, 0.03 \%$ to $12.8 \%$ and $0.03 \%$ to $9.3 \%$ in back up heating, hybrid heating and solar heating respectively. 


\section{Conclusion}

In the current paper, comprehensive review on passive solar dryer revealed the following outcomes.

- Greenhouse dryer with insulation in the north side wall is the most effective drying compared to the traditional greenhouse dryer.

- The thermal energy increased in the natural convection dryer by increasing the air mass flow rate.

- Usage of a porous absorber increases the temperature of air flow and velocity at the chimney.

- The more energy and greater efficiency are obtained by hybrid photovoltaic and thermal solar collector in indirect passive dryers.

- The water storage tank integrated with indirect dryer is used for heat energy storing and supplies the heat during off sunshine hours.

- The energy storage and better performance are achieved by black painted pebble bed absorber in the mixed mode dryer.

- The rock pebble used as energy storage in the concrete absorber of the mixed mode dryer.

- The better performance during low radiation is achieved by integrating the backup heater with dryer.

- The biomass plant uses the thermal back up for mixed mode dryer. The flue gas from biomass plant utilizes in recovery dryer.

- The mixed mode dryer constructed like tent shows better performance.

- Adopting multiple metallic plates in concentrator of mixed mode dryer shows the better economic performance compared to active dryers.

The following suggestions are provided for future works.

- The integration of the passive solar dryer with other solar equipment like solar cooker, solar water heater etc. may be the economical investment and better utilization of solar energy.

- The different types of composite materials can be adapted for collectors.

- The optimization of different materials and different thickness of the absorber will get a better drying performance of specific products.

\section{References}

1) Udomkun P, Romuli S, Schock S, Mahayothee B, Sartas M, Wossen T, et al. Review of solar dryers for agricultural products in Asia and Africa: An innovation landscape approach. Journal of Environmental Management. 2020;268:110730. Available from: https://dx.doi.org/10.1016/j.jenvman.2020.110730.

2) Toshniwal U, Karale S. A review paper on solar dryer. International Journal of Engineering Research and Applications. 2013;3:896-902. Available from: https://www.academia.edu/26690450/A_review_paper_on_Solar_Dryer.

3) Sharma A, Chen CR, Lan NV. Solar-energy drying systems: A review. Renewable and Sustainable Energy Reviews. 2009;13(6-7):1185-1210. Available from: https://dx.doi.org/10.1016/j.rser.2008.08.015.

4) Kapadiya S, Desai MA. Solar Drying of Natural and Food Products: A Review. International Journal of Agriculture and Food Science Technology. 2014;5:565576. Available from: https://www.academia.edu/9031085/Solar_drying_of_natural_and_food_products_a_review.

5) Borah A, Hazarika K, Khayer SM. Drying kinetics of whole and sliced turmeric rhizomes (Curcuma longa L.) in a solar conduction dryer . Information Processing in Agriculture . 2015;2(2):85-92. Available from: http://dx.doi.org/10.1016/j.inpa.2015.06.002.

6) Chauhan PS, Kumar A. Performance analysis of greenhouse dryer by using insulated north-wall under natural convection mode. Energy Reports. 2016;2:107-116. Available from: https://dx.doi.org/10.1016/j.egyr.2016.05.004.

7) Tiwari S, Tiwari GN. Thermal analysis of photovoltaic-thermal (PVT) single slope roof integrated greenhouse solar dryer. Solar Energy. 2016;138:128-136. Available from: https://dx.doi.org/10.1016/j.solener.2016.09.014.

8) Nimrotham C, Songprakorp R, Thepa S, Monyakul V. Experimental Research of Drying Red Chili by Two Methods: Solar Drying and Low - Temperature System Drying. Energy Procedia. 2017;138:512-517. Available from: https://dx.doi.org/10.1016/j.egypro.2017.10.237.

9) Singh M, Sethi VP. On the design, modelling and analysis of multi-shelf inclined solar cooker-cum-dryer. Solar Energy. 2018;162:620-636. Available from: https://dx.doi.org/10.1016/j.solener.2018.01.045.

10) Chen W, Qu M. Analysis of the heat transfer and airflow in solar chimney drying system with porous absorber. Renewable Energy. 2014;63:511-518. Available from: https://dx.doi.org/10.1016/j.renene.2013.10.006.

11) Finck-Pastrana AG. Nopal (Opuntia Lasiacantha) Drying Using an Indirect Solar Dryer. Energy Procedia. 2014;57:2984-2993. Available from: https://dx.doi.org/10.1016/j.egypro.2014.10.334.

12) Romero VM, Cerezo E, Garcia MI, Sanchez MH. Simulation and Validation of Vanilla Drying Process in an Indirect Solar Dryer Prototype Using CFD Fluent Program. Energy Procedia. 2014;57:1651-1658. Available from: https://dx.doi.org/10.1016/j.egypro.2014.10.156.

13) Musembi MN, Kiptoo KS, Yuichi N. Design and Analysis of Solar Dryer for Mid-Latitude Region. Energy Procedia. 2016;100:98-110. Available from: https://dx.doi.org/10.1016/j.egypro.2016.10.145.

14) Slimani MEA, Amirat M, Bahria S, Kurucz I, Aouli M, Sellami R. Study and modeling of energy performance of a hybrid photovoltaic/thermal solar collector: Configuration suitable for an indirect solar dryer . Energy Conversion and Management. 2016;125:209-221. Available from: http: //dx.doi.org/10.1016/j.enconman.2016.03.059. 
15) Essalhi H, Tadili R, Bargach MN. Conception of a Solar Air Collector for an Indirect Solar Dryer. Pear Drying Test. Energy Procedia. 2017;141:29-33. Available from: https://dx.doi.org/10.1016/j.egypro.2017.11.114.

16) Essalhi H, Benchrifa M, Tadili R, Bargach MN. Experimental and theoretical analysis of drying grapes under an indirect solar dryer and in open sun. Innovative Food Science \& Emerging Technologies. 2018;49:58-64. Available from: https://dx.doi.org/10.1016/j.ifset.2018.08.002.

17) Swami VM, Autee AT, Anil TR. Experimental analysis of solar fish dryer using phase change material. Journal of Energy Storage. 2018;20:310-315. Available from: https://doi.org/10.1016/j.est.2018.09.016.

18) Zoukit A, Ferouali HE, Salhi I, Doubabi S, Abdenouri N. Takagi Sugeno fuzzy modeling applied to an indirect solar dryer operated in both natural and forced convection. Renewable Energy. 2019;133:849-860. Available from: https://dx.doi.org/10.1016/j.renene.2018.10.082.

19) Emetere ME, Hayelom M, Kassaye A, Hailesilassie A, Gebrehiwot M, Vanierschot M. Design and Construction of Fruit Solar Drier. Procedia Manufacturing. 2019;35:674-680. Available from: http://dx.doi.org/10.1016/j.promfg.2019.06.009.

20) Ugwu SN, Ugwuishiwu BO, Ekechukwu OV, Njoku H, Ani AO. Design, construction, and evaluation of a mixed mode solar kiln with black-painted pebble bed for timber seasoning in a tropical setting. Renewable and Sustainable Energy Reviews. 2015;41:1404-1412. Available from: https://dx.doi.org/ 10.1016/j.rser.2014.09.033.

21) Dejchanchaiwong R, Arkasuwan A, Kumar A, Tekasakul P. Mathematical modeling and performance investigation of mixed-mode and indirect solar dryers for natural rubber sheet drying. Energy for Sustainable Development. 2016;34:44-53. Available from: https://dx.doi.org/10.1016/j.esd.2016.07.003.

22) Sekyere CKK, Forson FK, W F. Adam Experimental investigation of the drying characteristics of a mixed mode natural convection solar crop dryer with back up heater. Renewable Energy. 2016;92:532-542. Available from: http://dx.doi.org/10.1016/j.renene.2016.02.020.

23) Yassen TA, Al-Kayiem HH. Experimental investigation and evaluation of hybrid solar/thermal dryer combined with supplementary recovery dryer. Solar Energy. 2016;134:284-293. Available from: https://dx.doi.org/10.1016/j.solener.2016.05.011.

24) Mehta P, Samaddar S, Patel P, Markam B, Maiti S. Design and performance analysis of a mixed mode tent-type solar dryer for fish-drying in coastal areas. Solar Energy. 2018;170:671-681. Available from: https://dx.doi.org/10.1016/j.solener.2018.05.095.

25) Ssemwanga M, Makule E, Kayondo SI. Performance analysis of an improved solar dryer integrated with multiple metallic solar concentrators for drying fruits. Elsevier BV. 2020. Available from: https://dx.doi.org/10.1016/j.solener.2020.04.065. doi:10.1016/j.solener.2020.04.065.

26) Mohammed S, Fatumah N, Shadia N. Drying performance and economic analysis of novel hybrid passive-mode and active-mode solar dryers for drying fruits in East Africa. Journal of Stored Products Research. 2020;88:101634. Available from: https://dx.doi.org/10.1016/j.jspr.2020.101634.

27) César LVE, Lilia CMA, Octavio GV, Isaac PF, Rogelio BO. Thermal performance of a passive, mixed-type solar dryer for tomato slices (Solanum lycopersicum). Renewable Energy. 2020;147:845-855. Available from: https://dx.doi.org/10.1016/j.renene.2019.09.018.

28) Sekyere CKK, Adams FW, Davis F, Forson FK. Mathematical modelling and validation of the thermal buoyancy characteristics of a mixed mode natural convection solar crop dryer with back up heater. Scientific African. 2020;8:e0441. Available from: https://dx.doi.org/10.1016/j.sciaf.2020.e00441. 